\title{
Social remittances and the changing transnational political landscape
}

\author{
Thomas Lacroix $^{1 *}$ (D) Peggy Levitt ${ }^{2}$ and Illka Vari-Lavoisier ${ }^{3,4}$
}

\author{
* Correspondence: \\ thomas.lacroix@univ-poitiers.fr \\ ${ }^{1}$ CNRS research Fellow, Deputy \\ Director of Migrinter, Université de \\ Poitiers, Poitiers, France \\ Full list of author information is \\ available at the end of the article
}

\begin{abstract}
The term "social remittances" was coined over fifteen years ago to capture the notion that, in addition to money, migration also entails the circulation of ideas, practices, skills, identities, and social capital also circulate between sending and receiving communities. The articles in this special issue, which are primarily about migration and politics, drive forward research on social remittances by examining understudied areas such as Poland, Mali, the Ivory Coast, Tunisia, and Senegal. They elucidate transnational politics by showing how emigrants influence social protests, elections, and calls for greater transparency or reform. They bring to light the social underpinnings of social and economic remittance exchanges and the ways in which material constraints shape social remittance circulation. Finally by bringing discussions of the circulation of people and money into conversation with discussions about the circulation of culture and objects, they pave the way toward a better understanding of how objects and subjects, structures and agents, although ontologically distinct, maintain a reciprocal relationship of co-production.
\end{abstract}

Keywords: Transnationalism, Voting behaviour, Social remittances, Transnationalism, Migration politics, Emigration, Economic sociology

The term "social remittances" was coined over fifteen years ago to highlight that in addition to money, ideas, practices, social capital, and identities also circulated between sending and receiving communities (Levitt, 1998). These iterative circulatory exchanges reinforce and are reinforced by other forms of cultural circulation. They are distinct from them, however, because they are conveyed interpersonally between individuals who learn of, adapt, and diffuse ideas and practices through their roles in families, communities, and organizations (Levitt, 2015). The concept of social remittances, and the array of symbolic exchanges taking place in transnational spaces that it brings into focus, marked a turning point in migration scholarship that, until that time, had largely focused on financial transfers.

To be sure, economic remittances are important (Gubert, Lassourd \& Mesplé-Somps, 2010) and they involve large sums: according to World Bank projections, international migrants were expected to remit more than $\$ 550$ billion in earnings in 2013, of which $\$ 414$ billion will flow to developing countries. But if we only focus on money at the expense of the people, objects, skills, and ideas that circulate within transnational social fields, our analysis of the migration - development nexus remains incomplete. Recognizing this, many scholars have taken up this call, helping to revisit, redefine, and extend how social remittances are conceptualized and link these discussions to other social

(c) The Author(s). 2016 Open Access This article is distributed under the terms of the Creative Commons Attribution 4.0 International License (http://creativecommons.org/licenses/by/4.0/), which permits unrestricted use, distribution, and reproduction in any medium, provided you give appropriate credit to the original author(s) and the source, provide a link to the Creative Commons license, and indicate if changes were made. 
science and policy debates (Kapur, 2010, 2014; Boccagni \& Decimo, 2013; Chauvet \& Mercier, 2014).

This special issue showcases and synthesizes recent developments in this scholarship based on a conference entitled "Following the Flows: Transnational Approaches to Intangible Transfers", held at Princeton University in September 2014. This conference gathered sociologists, demographers, development economists, anthropologists, political scientists, or geographers. Our interdisciplinary debate brought to light the proliferation of various terminologies across disciplines, including "political remittances," "intangible flows," "democratic diffusion," "transfers of norms," or "health transfers" that ultimately document the different facets of one core phenomenon: that of social remittances.

This special issue brings new insights to these debates which, to date, have largely focused on social transfers emanating from the U.S.; indeed this volume explores new research sites, such as Poland, and pays welcome attention to understudied areas such as Africa through case studies of the impact of social remittances transfers on Mali, Ivory Coast, Tunisia, and Senegal.

It also contributes new insights by focusing on the transnational mechanics of political change in sending areas. If the political influence of emigrants can be observed during elections, social protests, or calls for greater transparency or reform, this influence is the result of the permanent and long standing interactions migrants maintain with their family and friends. The papers elucidate the processes and channels through which this influence is exerted. We believe this line of inquiry is critical "because diffusion depends on relationships between actors, networks are key" (Levitt \& Merry, 2009, p. 444). How these work, however, and how they contribute to patterns of cultural circulation remains understudied.

In a world on the move, local development processes increasingly shape and are shaped by global cultural circulation. A focus on social remittances drives home how individuals who build lives across distinct geographic spaces also translate and diffuse ideas and perceptions from one context to another. From their strategic positions as bridge builders and translators, migrants can reframe and vernacularize global norms (such as "transparency" or human rights). The translation of global norms into locally applicable and usable concepts empowers local activists and, hence, can contribute to (both) powerful (negative and positive) change (Levitt \& Merry, 2009).

The contributions to this volume show how, like the circulation of people, material constraints also shape the circulation of ideas and practices. Although this has been largely overlooked in the literature to date, this volume shows that the circulation of social remittances is shaped by the interpersonal, sometimes intimate, links between migrants and non-migrants, links that are themselves embedded in local dynamics, national historical contexts, and broader geopolitical dynamics. Just as the circulation of people and money reflects the unequal relationship between individuals, organizations, and nations, so it influences the circulation of ideas and practices.

Bringing discussions of the circulation of people and money into conversation with discussions about the circulation of culture and objects paves the way toward a better understanding of how "objects and subjects, structures and agents, although ontologically distinct, maintain a reciprocal relationship of co-production" (Lacroix, 2014). Shedding light on how the material and symbolic dynamics of the global circulation of 
people and culture interrelate, and identifying circulatory patterns, advances the study of integrated migration systems by producing a more comprehensive conceptual framework that takes into account a broader array of the complex dynamics that make up our interconnected world.

While the transnational turn in migration studies drove home the need to analyze sending and receiving country dynamics at the same time, scholars struggled with how to translate these theoretical insights into rigorous, feasible empirical research. Another important contribution of this volume, then, is the light it sheds on and the innovative models and tools it provides for understanding and evaluating the impact of the multisitedness and multi-layeredness of transnational social fields. By focusing on strategic events such as elections (Chauvet \& Mercier, 2014; Jaulin and Sasse \& Ahmadov or Vari-Lavoisier this issue), authors analyze the local variations of the same event in different countries.

Other contributors simultaneously collected data in migrants' countries of origin and destination (see Vickstrom and Vari-Lavoisier, this issue) or in several countries of destination (Chauvet \& Mercier, 2014; Jaulin and Vari-Lavoisier this issue) bringing new empirical evidence to the long- standing question of the differentiated impact of migration according to migrants' countries of destination. Some authors merge several scales of analysis (see Jaulin's multilevel maps, this issue) or conduct multi-level surveys: by doing so, they unravel the interpersonal and locally-embedded (micro) processes underpinning national and global (macro) outcomes. Their results revealed that international mobility not only affects migrants' preferences but also the political perceptions and behaviors of their relatives and friends in their countries of origin.

Below, we summarize Let us now summarize some key points from the articles in this volume.

Some papers highlight the effects of social remittances on the political orientations of migrants and non-migrants. Both Chauvet and Mercier (2014) and Jaulin (this issue), show that changes in political attitudes vary when the group moves to different destinations. They suggest that while exposure to certain political regimes and procedures may hold sway, its importance may be overestimated. Indeed, as Chauvet, Gubert and Mesplé-Somps (this issue) write "Some less democratic destinations may attract individuals who care less for democracy." In other words, this differential effect may be linked to the characteristics of emigrants to begin with. Jaulin's work, which reveals differences in the impact of social remittances within sending countries, suggests that more than just exposure to national regimes is at stake. Exposure to regional and urban politics also matter. Chauvet et al. find that migrants' level of social inclusion influences their political orientations. The level of interaction with the host society is positively correlated with greater distrust and a critical stance toward sending country institutions.

Gwendolyn Sasse and Anar Ahmadov's paper complements this view. Using multisited, multi-layered research, which combines surveys at polling stations with interviews with Polish migrants in the UK and with their relatives in Poland, they address how migration transforms migrants' political imagination. They show how the daily experience of living in multicultural Britain transformed migrants' political views on Poland. In addition, they show that migrants are more interested in politics than before they left. It seems as if spatial distance created greater social distance and reflexivity, leading people to question their views about themselves and their origin society. 
The legal context shaping migrants' social incorporation directly and indirectly influences social remittance effects. Clearly, immigration law plays a major role. Indeed several contributors chronicle how legal frameworks influence social remittance circulation and how immigration laws facilitate or thwart migrants' transnational practices. Erik Vickstrom and Cris Beauchemin examine how laws constrain mobility trajectories within host countries which, in turn, influence what migrants are exposed to, the extent to which they may maintain long distance relations with their kith and kin at home, and what they ultimately remit. Likewise, Jaulin shows how legal status in countries of destination influence migrants' impact on their homeland.

Whether migrants are encouraged or allowed to organize and participate politically does too. Jaulin found that voter turnout differed significantly when voting procedures and regulations were modified (see also Braconnier \& Dormagen, 2007 cited by Jaulin in this issue). Furthermore, Jaulin's work sheds light on some of the dynamics fueling political Islamism in French suburbs, another potential social remittance. Residential and occupational segregation affect and are affected by immigration and social policies but that is not all. How Tunisian migrants living in Parisian neighborhoods vote starkly contrasts with the progressive attitudes predominating in the inner city. The Islamist support pervading the northern working class suburbs drives home that the circulation of ideas and practices cannot be divorced from the socioeconomic backdrop against which it occurs.

A second group of articles explores the material dimensions of transnational circulation by looking at the relationship between economic transfers and social remittances-a question that, to date, has been largely overlooked A comparative analysis across cases, including Latin America and West Africa, reveals interesting variations, particularly with respect to the channels through which social remittances circulate.

In Latin America, Meseguer, Lavezzolo and Aparicio investigate how migrants influence their non- migrant family members through cross-border conversations. Using data from over 18 countries, the authors find that people with emigrant family members, with whom they are in frequent contact, often hold more favorable views of the state. The authors show that looking at the impact of monetary transfers "without taking into account social learning effects" leads us to disregard critical dynamics. They believe that much scholarship to date overestimates the impact of economic remittances.

Other articles move us beyond the opposition between economic and social transfers to analyze the multidimensional ties migrants maintain to their homelands. Vickstrom and Beauchemin reveal how the circulation of economic remittances relates to and is influenced by other kinds of transnational practices. They analyze how restrictive immigration laws affect the remitting behaviors of migrants by shaping their ability to maintain ties with their relatives in their countries of origin and their ability to travel back and forth. The authors emphasize the extent to which transnational ties rely on concrete connections: co-presence and phones calls, visits, and visas. By doing so, they show that economic remittances are part and parcel of a wider set of transnational practices. If we treat the economic, social, and cultural aspects of migration as separate spheres, we miss their deep interconnectedness and therefore the interconnectedness of their effects.

Along these same lines, Vari-Lavoisier explores the intersection between economic and social transfers by comparing the Senegalese diaspora in the U.S. and in France. Drawing upon economic sociology, this paper studies the material dynamics that underlie social remittance circulation. Vari-Lavoisier sees economic remittances as 
crucial to social remittance circulation because they are a key driver of the transnational ties maintained between expatriate Senegalese and their kin. She finds that, in addition to the different socioeconomic profiles of Senegalese-born migrants in the U.S. and France, the extent to which they engage in homeland politics is also strongly influenced by the extent of their homeland economic ties. Therefore, like Beauchemin and Vickstrom, she finds that economic and social transfers are strongly related. Moreover, she argues that monetary transfers enhance migrants' ability to promote their views, thereby magnifying the impact of the social remittances they introduce. The circulation of ideas and practices is grounded in material conditions and enabled and constrained by material resources.

In sum, these articles elucidate the complex relationship between the social infrastructure of transnational connections, remittances and their political implications. Our contributors advance scholarly debates in several ways: (1) by piloting innovative, interdisciplinary methods that reveal the role of networks in cultural circulation; (2) by bringing to light the legal and socioeconomic factors affecting who transfers what; (3) by beginning to untangle the complicated relationship between social remittance transfers and broader inequalities; (4) by elucidating processes of vernacularization and what contributes to social remittances' scaling up and out; and (5) by calling into question some of the epistemological assumptions underlying migration studies and the social sciences in general. Our contributors pave the way toward a next generation of migration scholarship that brings discussions about the migration of people into direct conversation with those about the migration of material and symbolic goods. By doing so, they point the way to a more holistic, integrated understanding of migration systems which takes objects and subjects; structures and agents; and goods, ideas, and behaviors as intimately related and co-produced within the transnational social fields in which they are embedded.

\footnotetext{
Author details

${ }^{1}$ CNRS research Fellow, Deputy Director of Migrinter, Université de Poitiers, Poitiers, France. ${ }^{2}$ Department of Sociology, Wellesley College, Robert Schuman Fellow, European University Institute, Co-Director, Transnational Studies Initiative, Harvard University, Cambridge, USA. ${ }^{3}$ Center for the advanced study of India, University of Pennsylvania, Philadelphia, USA. ${ }^{4}$ DIAL, Institut de Recherche pour le Developpement, Paris, France.
}

Received: 17 September 2015 Accepted: 13 May 2016

Published online: 03 November 2016

\section{References}

Boccagni, P., Decimo, F. (2013). Mapping social remittances. Migration Letters, 10(1), 1-10.

Braconnier, C, \& Dormagen, J-Y. (2007). La démocratie de l'abstention. Aux origines de la démobilisation électorale en milieu populaire [Democracy of abstention. The origins of electoral demobilizing in the working class]. Collection Folio actuel (n 129). Paris: Gallimard. http://www.gallimard.fr/Catalogue/GALLIMARD/Folio/Folio-actuel/Lademocratie-de-l-abstention.

Chauvet, L., \& Mercier, M. (2014). Do return migrants transfer political norms to their origin country? Evidence from Mali. Paris, Dauphine University. https://ideas.repec.org/a/eee/jcecon/v42y2014i3p630-651.html

Gubert, F., Lassourd, T., \& Mesplé-Somps, S. (2010). Transferts de fonds des migrants, pauvreté et inégalités au Mali: Analyse à partir de trois scénarios contrefactuels [Migrant Remittances, Poverty and Inequalities in Mali: an analysis drawing on three contrafactual scenarios]. Revue économique, 61 (6), 1023-1050. doi:10.3917/reco.616.1023

Kapur, D. (2010). Diaspora, development, and democracy the domestic impact of international migration from India. Princeton: Princeton University Press.

Kapur, D. (2014). Political effects of international migration. Annual Review of Political Science, 1(17), 479-502.

Lacroix, T. (2014). Conceptualizing transnational engagements: a structure and agency perspective on (Hometown) transnationalism. International Migration Review, 48(3), 643-79.

Levitt, P. (1998). Social remittances: migration driven local-level forms of cultural diffusion. International Migration Review, 32(4), 926-48.

Levitt, P. (2015). Artifacts and allegiances: how museums put the nation and the world on display. Oakland: University of California Press.

Levitt, P., \& Merry, S. (2009). Vernacularization on the ground: local uses of global women's rights in Peru, China, India and the United States. Global Networks, 9(4), 441-61. 